\title{
„OBRZEZANY” GREK I „PRAWDZIWY” ŻYD W ŚWIETLE RZ 1,18-3,20
}

Od pierwszych słów Listu do Rzymian dla Pawła jest oczywiste, że Dobrą Nowiną dla całej ludzkości jest osoba i dzieło Jezusa Chrystusa, ponieważ Bóg objawił w Nim pełnię swojej sprawiedliwości oraz dał jej w Nim swą moc wiodącą ku zbawieniu (1,3-9; 1,16-17). Skoro tak, to dlaczego zamiast przejść od razu do owej fundamentalnej dla niego prawdy chrystologiczno-soteriologicznej o objawieniu się zbawczej sprawiedliwości Bożej, buduje najpierw obszerny wywód poświęcony karzącej sprawiedliwości: Bożemu gniewowi, sądowi i odpłacie $(1,18-3,20)$ ? Czy dlatego, że uważa ją za niezbędny warunek dostąpienia owej zbawczej mocy w Jezusie? Zatem, czy pogrążona w grzechach ludzkość musi najpierw uznać swą beznadziejną sytuację przed Stwórcą i Sędzią, upokorzyć się przed Nim w postawie pokuty, następnie zostać przez Niego osądzona i ukarana, by dopiero w takiej kondycji dostąpić Jego miłosiernego przebaczenia? Czy to wszystko najpierw musi wydarzyć się w jej relacji z Bogiem, zanim usłyszy słowa Ewangelii o łaskawym usprawiedliwieniu przez wiarę w Jezusa Chrystusa (3,21-31)? Czy to z tych właśnie racji apostoł początkowo broni pozytywnej roli Prawa Mojżeszowego w objawianiu woli Bożej (1,18-3,20), aby później przejść do zakwestionowania dotychczasowego porządku Prawa, jego autorytetu i dalszej aktualności w dziejach zbawienia? To dlatego podkreśla wagę karzącej sprawiedliwości Bożej w stosunku do grzesznej ludzkości, aby jeszcze bardziej wyraziście wskazać na fundamentalnie nową jakość zbawczej sprawiedliwości objawionej w Jezusie jako jedynej odtąd mocy zbawczej dla każdego człowieka? I, pozostając w tej logice retorycznej, należy konsekwentnie zapytać, ku czemu Paweł w całej tej argumentacji zmierza? Czy ku uzasadnieniu słuszności odrzucenia dotychczas uznawanych różnic i granic kategorii religijnych Żyda 
i Greka, i wprowadzenia na ich miejsce nowych kategorii: „obrzezanego” Greka i „prawdziwego” Żyda? Jeżeli rzeczywiście taka jest jego intencja, to jakim celom religijnym i teologicznym ma to służyć? Czy wykreowanie owych kategorii Greka i Żyda stanowi główny cel jego argumentacji w sekcji 1,18 - 3,20 po to, żeby zbudować na początku listu właściwy fundament na którym będzie mógł budować dalsze twierdzenia teologiczne ważne dla Kościoła w Rzymie?

\section{Żydzi i Grecy wobec Bożego sądu}

Podsekcja 1,18 - 3,201 zbudowana jest według ówczesnego wzorca kompozycyjnego. ${ }^{2}$ Paweł nie dzieli tu całej ludzkości według znanego mu prostego judaistycznego klucza na pobożnych i dobrych Żydów oraz bezbożnych i złych Greków (pogan). ${ }^{3}$ Świadczą o tym stosowane tu ogólne określenia, takie jak: „ci ludzie, którzy ”, które mogą odnosić się zarówno do jednych jak i do drugich. Podobnie też, gdy stosuje słowo pas (,wszystko”, „wszelka”, „wszelaka”), to bardziej opisuje nim same działania niż osoby działające (1,18.29). Dlatego też, gdy mówi o objawiającym się gniewie Bożym, to nie odnosi go bezpośrednio do grup religijnych (Żydów i Greków), lecz do wszelkiej niesprawiedliwości popełnianej przez ludzi występujących przeciwko prawdzie. Ci zaś mogą być zarówno Żydami jak i Grekami, i nie wszyscy, lecz tylko jakaś część z nich (1,29-31; 2,1-5). Apostoł

1 Punktem wyjścia prowadzonych analiz egzegetycznych będzie kompozycja listu zaproponowana przez: J-N. A 1 e t t i, List do Rzymian w: W.R. F a r m e r (red.), Międzynarodowy Komentarz do Pisma Świętego. Komentarz katolicki i ekumeniczny na XXI wiek, Warszawa 2000, s. 1411n. Wygląda ona następująco: Praescriptum (1,1-7); Exordium (1,8-17) kończące się propositio do całego listu (1,16-17); Probatio składające się z trzech sekcji tematycznych: A) Żyda i Greka usprawiedliwia jedynie wiara (1,18-4,25), B) Nowe życie i nadzieja ochrzczonych (5-8), C) Izrael i poganie: przyszłość Izraela (9-11); Napomnienia (12,1-15,13); Peroratio (15,14-21); Informacje i pozdrowienia końcowe (15,22-33 + 16,1-27), z Postscriptum w 15,33.

2 Propositio-Probatio-Peroratio: Propositio (1,18); Probatio (1,19-3,18); Peroratio (3,19-20); por. tamże, s. 1416.

3 Oba terminy są kategoriami religijnymi: Żydzi i wszyscy inni, nie-Żydzi (Grecy/poganie); por. tamże, s. 1418. 
nie podaje tu żadnych wskazówek umożliwiających określenie ich liczby oraz statusu religijnego. Bardzo istotne jest jednak, że przy ich ocenie kieruje się kryteriami moralnymi, osądza ich postawy, zachowania i działania. Jako pierwsze wymienia i charakteryzuje dwie grupy takich ludzi. Najpierw pisze o tych wszystkich, którzy czynią zło i akceptują takie działanie u siebie i u innych (1,19-32), a następnie opisuje grupę tych, którzy krytykują i osądzają tych z pierwszej grupy, lecz sami dopuszczają się identycznej niesprawiedliwości (2,1-8). Co do osądu obu grup, apostoł nie pozostawia wątpliwości, że jednych i drugich dosięgnie sąd i kara Boża (2,9-11), ${ }^{4}$ nagrodę zaś otrzymają ci, którzy postępują sprawiedliwie, zarówno pochodzący spośród Żydów jak i Greków (2,14-15). ${ }^{5}$ Od 2,17 Paweł przechodzi do charakterystyki trzeciej, również negatywnej, grupy ludzi. Stanowią ją Żydzi głoszący dobro, lecz dopuszczający się zła (2,17-24). Apostoł i tym razem nie określa ich liczby. Mając jednak na uwadze fakt, że unika tu również stosowania słowa „wszyscy” (pas), to i tym razem ma na myśli tylko część Żydów. ${ }^{6} \mathrm{~W}$ porównaniu do charakterystyki dwóch pierwszych grup, w opisie tej właśnie grupy dokonuje zmiany jakościowej, ponieważ w tym przypadku odnosi się do sfery ich świadomości. Zapewne chce w ten sposób wykazać ich odpowiedzialność za to, co czynią, gdyż wiedzą (mają świadomość), jak osądza takie czyny Prawo dane im przez Boga. Nie mogą wymówić się, że nie mają właściwego zrozumienia istoty Prawa Mojżeszowego oraz roli, jaką powinno odgrywać w ich życiu. Zdają sobie doskonale sprawę z tego, że jest ono objawieniem woli Bożej danej im do przestrzegania. Świadomość tego potwierdzają swym postępowaniem, bowiem chlubią się nim i głoszą je innym jako objawioną jedynie im w wyjątkowy sposób wolę Bożą. Niestety, sami

4 Apostoł wyraźnie zaznacza, że nie w s z y s c y 1 u d z i e, lecz w s z y s c y $1 \mathrm{udzi}$ e czynią cy zło, bez żadnego wyjątku, poniosą sprawiedliwą karę.

5 Apostoł zakłada istnienie grupy ludzi dobrych, którzy będą wynagrodzeni przez Boga, ponieważ tego wymaga Jego sprawiedliwość.

6 Zakłada więc istnienie grupy pobożnych Żydów wiernie przestrzegających Prawa. 
postępują wbrew niej, dopuszczając się tym samym niesprawiedliwości. Takie postępowanie jest znacznie gorzej oceniane przez Boga niż poprzednie (krytyka zła i jednoczesne czynienie go) i pociąga za sobą znacznie większą winę, a tym samym i jeszcze głębsze pohańbienie spadające na każdego Żyda mającego takie właśnie rozumienie istoty i roli Prawa w jego życiu osobistym i narodu.?

W argumentacji przedstawionej w 1,19-32 Paweł podejmuje szczególny wysiłek zmierzający do wykazania adresatom, że istnieje ścisły związek między ludzkim działaniem a Bożą reakcją na nie. Dlatego też każdy człowiek musi czuć się odpowiedzialny przed Bogiem za swoje czyny. Powinna ona przejawiać się w pełnym uznaniu sprawiedliwości kary Bożej wymierzonej mu z powodu popełnionego zła. Aby jednak wzbudzić taką świadomość w adresatach, apostoł cały ten tekst konstruuje według retorycznego schematu, w którym trzykrotnie powtarza się ta sama zasada kompozycyjna, za każdym razem coraz bogatsza w treść i dzięki temu z coraz to wyrazistszym i głębszym przesłaniem: działanie ludzkie (1,19-23) - reakcja Boga $(1,24)$; działanie ludzkie $(1,25)$ - reakcja Boga (1,26-27); działanie ludzkie (1,28a) - reakcja Boga (1,28b-31). Dzięki zastosowaniu takiej właśnie konstrukcji retorycznej Paweł jeszcze bardziej wzmacnia siłę zawartej tu argumentacji zmierzającej do uświadomienia czytelnikowi, że wskazani grzesznicy postępują w sposób niewybaczalny przed Bogiem i nie mogą w żaden sposób wymówić się przed Nim od winy $(1,20)$. Wzbudzenie takiego stanu świadomości w adresatach pozwala apostołowi podjąć argumentację uzasadniającą sprawiedliwą reakcję Boga, która jest zawsze odpowiedzialna i proporcjonalna do popełnionego zła. Bóg jednak nie potępia definitywnie grzesznika, jak tego oczekiwałaby sprawiedliwość ludzka. Nie unicestwia swego stworzenia z powodu jego grzechów, lecz karze je zawsze z umiarem, wzywając przez to do nawrócenia; odwrócenia się od zła i powrotu do pełnienia Jego woli. ${ }^{8}$

7 Por. J-N. A l e t t i, List do Rzymian, s. 1416n.

8 Por. tamże, s. 1418; L.T. J o h n s o n, Reading Romans. A Literary and Theological Commentary, Macon 2001, s. 32-36; J.M. B o i c e, Romans I. Justification by faith. Romans 1-4. Grand Rapids 1991, s. 127-136; S. W it k o w s k i, Powszechny 
Od 1,19 do 2,29 apostoł przedstawia trzy grupy grzeszników, które co prawda różni status religijny, ale też istnieje coś, co je ze sobą łączy. W 1,19-32 i 2,1-16 pisze o Żydach i Grekach, a w 2,17-29 tylko o samych Żydach. ${ }^{9}$ Drugą i trzecią grupę grzeszników łączy ta sama wewnętrzna sprzeczność. Rodzi się ona $z$ tego, że każdy $\mathrm{z}$ nich potępia innych z powodu ich złego postępowania, tymczasem sam postępuje identycznie jak ci, których tak surowo osądza (2,1-16). Innych uczy, że nie wolno kraść - a sam kradnie, że nie wolno cudzołożyć - a sam cudzołoży, że należy brzydzić się bożkami - a sam okrada świątynie tych bożków. Wie, że każdym przekroczeniem Prawa znieważa Boga, bo innych tak naucza, a jednak nie jest $\mathrm{Mu}$ posłuszny $(2,17-24){ }^{10}$

wymiar grzechu (Rz 1,18-32), w: J. K r ę c idło (red.), Pozwólcie pojednać się z Bogiem, Studia Salettensia 1, Kraków 2007, s. 33-55.

9 Nie chodzi tu o wszystkich Żydów, nigdzie bowiem Paweł nie ma na myśli wszystkich, włącznie z wiernymi i pobożnymi.

10 Paweł korzysta tu z paralelizmu, aby jak najbardziej zrozumiale i przekonująco wykazać, na czym polega uwikłanie w wewnętrzne sprzeczności (A i A') oraz jakie są ich konsekwencje (B i B'); por. J-N. A le t t i, List do Rzymian, 1419.

\section{A (2,1-8)}

apostrofa człowiecze, kimkolwiek jesteś adres negatywnie: kogo sądzisz? innych sprzeczność sądząc innych, sam na siebie wydajesz

wyrok; sądzisz innych, a sam czynisz to, co oni

lekceważenie Boga nieuznawanie dobroci Boga

wykorzystanie Pisma w.6: aluzja do Ps 62,13

\author{
A' (2,17-24) \\ ty, Żyd \\ pozytywnie: gdzie szukasz chwały? \\ uczysz innych, a sam siebie nie uczysz; \\ głosisz, że nie wolno kraść, a sam krad- \\ niesz (x3) \\ znieważasz Boga \\ w. 24 cytuje Iz 52,5
}




\section{Równy status Żydów i Greków przed Bogiem}

W 2,1-8 Paweł dokonuje szczegółowej analizy czynów ludzkich. ${ }^{11}$ Wykazuje, że sam fakt posiadania Prawa Mojżeszowego nie daje gwarancji i nie sprawia automatycznie, że wszystkie dokonywane przez Żyda czyny są zgodne z wolą Bożą. ,Dobro” czynu wynikającego z przestrzegania Prawa, który to czyn Bóg zawsze wynagradza, nie polega na tym że jest wyłącznie skutkiem zachowania Prawa, lecz jego „dobro” leży w stałym trwaniu w „dobrych uczynkach”, czyli takich które wykraczają poza aktywność czysto ludzką i szukają jego Boskiego komponentu. Polega to na tym, że z jednej strony muszą one przyczyniać się do pomnażania oddawanej Bogu „czci” i „chwały”, z drugiej zaś, zbliżać osobę ludzką ku nieśmiertelności - tj. życia wiecznego z Bogiem. Zatem, aby czyn ludzki mógł być w swej istocie „dobry” z punktu widzenia Boga, to musi on być trwale ukierunkowany na Niego samego oraz na dar nieśmiertelności człowieka. Gdy chodzi o „zło”, które zawsze podlega Boskiej karze, to według Pawła może je zawierać również „dobry” czyn będący skutkiem zachowania Prawa. Tak się dzieje, jeśli jest on dokonywany wyłącznie ze względu na egoistyczne korzyści, czyli jest podyktowany jedynie względami ludzkimi, wykluczającymi z niego komponent Boski. W pełnieniu zarówno „dobrych” jak i „złych” czynów Żydzi mają pewną przewagę nad poganami z tego względu, że mogą cieszyć się przywilejem Prawa. Jednak - jak to uzasadnia apostoł - dla pogan nie musi być ono przedmiotem ich zazdrości, ponieważ to nie w nim leży Boże kryterium definitywnie rozstrzygające o tym czy dany czyn jest „dobry” czy też „zły”. Bóg bowiem nie ma względu na

B (2,9-16)

tożsamość najpierw Żyd, a potem Grek

Prawo bez Prawa / w Prawie; czynić to,

czego wymaga Prawo

napis; serce wypisane w ich sercach

wola Boga Bóg sądzi ukryte czyny
B' (2,25-29)

widzialny Żyd; ukryty Żyd

praktykowanie i zachowywanie Prawa

obrzezanie serca, nie według litery

pochwała... od Boga

${ }^{11}$ Zwrotem: „człowiecze, kimkolwiek jesteś”, apostoł sygnalizuje, że odnosi się tu do całej ludzkości, do wszystkich Żydów i nie-Żydów (Greków). 
osobę i nie kieruje się jej statusem religijnym. Jego wybór Żydów (9-11) oraz związany z tym przywilej pierwszeństwa $(3,1)$ nie oznacza wcale, że jakikolwiek Żyd może czuć się na tyle zadufanym w sobie samozwańczym sędzią, żeby zawłaszczyć Prawo otrzymane od Boga w celu osiągania egoistycznych, wyłącznie ludzkich korzyści. Dla Pawła, jakakolwiek by nie była różnica między Żydami i poganami, to i tak nie jest ona na tyle istotna, by była w stanie wpłynąć na podstawę i werdykt sądu Bożego. Bowiem Bóg sądzi czyn ludzki wyłącznie według kryterium ,prawdy” (2,2), to znaczy, patrzy i ocenia czy jest on zgodny z Jego wolą, czy też jej się sprzeciwia. Widzi On zarówno czyn zewnętrzny jak i wewnętrzny. Dostrzega wewnętrzną świętość lub zło, ponieważ doskonale zna serce człowieka, a będąc bezstronnym w osądzie jest sędzią sprawiedliwym. Każdemu udziela nagrody lub kary według tego, co uczynił zarówno czynem widzialnym jak i niedostrzegalnym dla ludzkiego oka (Jr 17,10; Prz 24,12). Te właśnie atrybuty odróżniają Go od ludzi, gdyż ci, będąc skłonnymi do korupcji, czynią się niezdolnymi do bezstronności (1Sm 16,7; 2Krn19,16n.). ${ }^{12}$ Bóg gdy przywraca sprawiedliwość to nie tylko karze złych, ale przede wszystkim naprawia wyrządzone przez nich zło, niezależnie od intencji tego, kto je wyrządził. Chroni pokrzywdzonych, czyniąc im zadość, ponieważ ich prawa zostały pogwałcone. ${ }^{13}$

12 Atrybut ten czyni z Boga kogoś bardzo bliskiego każdemu człowiekowi, który nie znajduje żadnego oparcia oraz bez określonego statusu dającego konkretne przywileje i korzyści (Pwt 1,16n.). Sprawiedliwość Boża nie jest jednoznaczna z egalitarną neutralnością, bowiem w przeciwieństwie do niej Bóg naprawia zło i chroni słabych.

13 Prawda o Bożej bezstronności często przewija się w księgach biblijnych (1Sm 16,7; 2 Krn 19,6n.; Pwt 10,17; Hi 34,19; Prz 18,5; 24,23-25; 28,21; Ps 82[81],1-4; Iz 11,3; Syr 4,22.27; 35,12-18; Mdr 6,7;). Również w literaturze judaistycznej prawda ta jest wyraźnie obecna (TesHi 4,7-9; 43,13; 3Ezd 4,39; Jub 5,12-16; 21,3-5; PsSal 2,15-18; 2,32-35; 2Ba 13,8-12; 44,2-4; AntBib 20,3n.; HenEt 638n.). Podobnie w księgach Nowego Testamentu: w odniesieniu do Boga (Dz 10,34; 15,8n.; Jk 2,1.9; 1P 1,17) i Jezusa (Mt 22,16; par. Mk 12,14; Łk 20,21); w Corpus Paulinum (Ga 2,6; Kol 3,25; Ef 6,9). Por. C.K. B a r re t, The Epistle to the Romans. Black's New Testament Commentary, London $1991^{2}$, s. 41-44.46; R. H a $1 \mathrm{~d}$ a n e, Exposition of the Epistle to the Romans, Escondido 1999, s. 92-95; J.-N. A l e t t i, List do Rzymian, s. 1420; 


\section{Tożsamość żydowska}

W 2,17-24 apostoł wskazuje na jednoznaczną tożsamość żydowską, ${ }^{14}$ w kształtowaniu której Prawo Mojżeszowe miało odgrywać decydującą rolę. ${ }^{15}$ Miało być ono rozumiane i przyjęte przez wszystkich Żydów jako objawiona wola Boża pozwalająca im właściwie poznać Jego samego i to wszystko co jest „dobre”. Miało kształtować zatem ich wewnętrzne myślenie i zewnętrze działanie. Każdy Żyd miał żyć z nią w pełnej zgodzie na drodze jej egzystencjalnego doświadczenia, aby poznawszy prawdziwego Boga głosić Go również reszcie ludzkości która Go nie znała. To dzięki Prawu mieli być oni dla pogan nauczycielami, przewodnikami i światłem wszelkiej wiedzy i prawdy o jedynym prawdziwym Bogu. ${ }^{16}$ To była ich najważniejsza misja związana z wyborem i powołaniem ich patriarchy Abrahama. Niestety, nie wszyscy Żydzi tej misji sprostali. Część z nich, choć doskonale o niej wiedziała i dobrze znała prawdę o Bogu oraz Jego wolę, to jednak ani nią nie żyła ani jej nie przekazała tym którzy

L.T. J o h n s o n, Reading Romans, s. 36-38; J.M. B o i c e, Romans I, s. 201-224; R. J e w e t t, Romans. A Commentary on the Book of Romans, Minneapolis 2007, s. 191-206.

14 Jednostka ta zbudowana jest $\mathrm{z}$ dwóch części: 2,17-20 (domniemania adresata); 2,21-24 (rzeczywistość, która jest zupełnie inna) w następującej kompozycji retorycznej.

a) 2,17-18: pozytywny związek między Żydami a Bogiem (przez Prawo)

ß) 2,19-20: pozytywny związek między Żydami a poganami (nauczyciel, przewodnik, światło)

ß’) 2,21-22: sprzeczność (sami siebie nie uczą)

๙') 2,23-24: sprzeczność (znieważanie Boga); por. J.-N. A l e t t i, List do Rzymian, s. 1421.

15 Zastosowanym na początku apostrofem „ty, Żyd” apostoł chce wstrząsnąć Żydami żyjącymi w wewnętrznej sprzeczności ze sobą. Chce ich przymusić niejako do zajrzenia we własne serca i dostrzeżenia w nich owej sprzeczności i nieobrzezania.

16 Jak wynika z przedstawionej tu argumentacji, Prawo według Pawła nie powinno być traktowane legalistycznie jako zbiór zakazów i nakazów, jako narzędzie służące budzeniu strachu przed Bogiem i Jego sądem. Sens Prawa to wartość pozytywna, a nie negatywna opresja. Inaczej to przedstawia w 2,12. Por. J.-N. A 1 e $t$ t i, List do Rzymian, s. 1421; C.K. B a r r e t, The Epistle to the Romans, s. 52n. 
jej nie znali. W ten sposób dopuścili się najcięższego ze wszystkich grzechów. Odrzucając bowiem misję zleconą im przez samego Boga wobec reszty świata, odrzucili de facto Jego samego. Dopuszczając się tego, stanęli na równi z poganami, którzy zamiast dzięki nim poznać prawdziwego Boga i żyć zgodnie z Jego Prawem, nadal „bluźnią Jego imieniu" $(2,24)$. Popełniony grzech w sposób oczywisty spowodował utratę przez nich tożsamości żydowskiej, co w konsekwencji pociąga za sobą sąd i karę, czego zresztą żąda nie tyle Paweł, ile samo Pismo; zatem sam Bóg w nim przemawiający. ${ }^{17}$

\section{Przywilej pierwszeństwa wobec sprawiedliwości Bożej}

W 2,1-8 Paweł wykazał, że Żydzi i poganie są równi przed Bogiem, mimo tego, że Żydzi uważają, iż Prawo, jakie otrzymali za pośrednictwem Mojżesza stawia ich w bardziej uprzywilejowanej sytuacji i daje im przywilej pierwszeństwa. ${ }^{18} \mathrm{~W} 2,12-15^{19}$ rozwija tę myśl, by udowodnić, że brak owego objawionego Prawa u pogan nie stawia ich ani w gorszej, ani w lepszej sytuacji przed Bogiem. Stwierdza, że to, co poganie mieli poznać o Bogu i Jego woli, zostało im dane przez Stwórcę w akcie stworzenia. Co więcej, odczytali zapisaną w sercu Jego wolę wzywającą ich do poznania Go na podstawie obserwacji dzieła stworzenia. Niestety, nie usłuchali jej jednak i nie oddali Mu czci jako jedynemu Bogu. Zamiast Niego uznali za bóstwa

17 Por. J.-N. A l e t t i, List do Rzymian, s. 1422; C.K. B a r r e t, The Epistle to the Romans, s. 53n.; L.T. J o h n s o n, Reading Romans, s. 41; J.M. B o i c e, Romans I, s. 247-256; R. J e w e t t, Romans, 219-230.

18 Paweł podkreśla ten fakt powtarzając dwukrotnie frazę: „,najpierw (...) Żyda, potem (...) Greka" (2,9.10).

19 Osoby Zapłata i sprawiedliwość

$\mathrm{a}=$ w. 12a: ci, którzy nie mają Prawa zapłata negatywna - bez Prawa

$\mathrm{b}=$ w. 12b: ci, którzy są w Prawie zapłata negatywna - według Prawa

$\mathrm{B}=$ w. 13: ci, którzy mają Prawo - pozytywny warunek zapłaty: wypełnić Prawo

A = w. 14-15: ci, którzy nie mają Prawa-pozytywny warunek zapłaty: słuchać sumienia.

Por. J.-N. A l e t t i, List do Rzymian, s. 1420. 
Jego stworzenia i to im ,oddali swoje serca”, zamieniając przez to „chwałę niezniszczalnego Boga na podobizny i obrazy śmiertelnego człowieka, ptaków, czworonożnych zwierząt i płazów", grzesząc w ten sposób przeciwko prawdziwemu Bogu (1,19-21). Jednakże Żydzi również grzeszyli, chociaż objawił się im Bóg w odrębny sposób i dał im swoje Prawo. Okazuje się więc - zgodnie z przedstawioną tu przez Pawła logiką - że jedni i drudzy stali się równi wobec Boga w nieposłuszeństwie i grzechu. W jego przekonaniu brak szczególnego objawienia i Prawa u pogan nie usprawiedliwia ich przed Bogiem i nie zamyka drogi przed Jego sądem i odpłatą (1,19-32). Podobnie jak posiadanie obu darów nie usprawiedliwia i nie zwalnia Żydów od sądu i kary z powodu ich grzechów. To, co mogłoby się zatem wydawać dla Żydów przywilejem i korzyścią, wcale się tym nie okazało. Podobnie jak i dla pogan brak jednego i drugiego przywileju nie okazał się korzystny, albowiem nie uchroniło ich to przed grzechami i Bożym sądem. Ostatecznie zarówno Żydzi jak i poganie będą sądzeni z powodu popełnionych grzechów, a nie na podstawie ich statusu religijnego. To nie on będzie stanowił dla Boga kryterium definitywnie rozstrzygające o tym, kto jest sprawiedliwy przed Nim, a kto nie. Jedynym kryterium jest Jego bezstronność oraz znajomość wszystkich czynów każdego człowieka, zarówno tych widocznych jak i tych ukrytych, ponieważ zna On doskonale każde serce ludzkie. To właśnie bezstronność i znajomość serca czyni Go sędzią sprawiedliwym. ${ }^{20}$

\section{Prawo Boże w sercu Greka}

Paweł podziela przekonanie, że nie wystarczy samo posiadanie Prawa, ani nawet jego doskonała znajomość. Obligatoryjne jest

20 Tylko Bóg zna ludzkie serce. I dlatego, aby się przekonać o winie, bada serce a nie postępowanie człowieka, (Pwt 4,29; 6,5; 1Sm 16,7; $1 \mathrm{Krl} \mathrm{8,39;} \mathrm{Jr} \mathrm{11,20;} \mathrm{12,3;}$ 17,10; 20,12; Ps 7,10; 17[16],3; 44[43],22; 139[138],23; Prz 15,11; 17,3; 21,2; 24,12); por. C.K. B a r r e t, The Epistle to the Romans, s. 46; R. H a $\mathrm{ld}$ a $\mathrm{n}$ e, Exposition of the Epistle to the Romans, s. 95; L.T. J o h n s o n, Reading Romans, s. 38-40. 
jeszcze jego przestrzeganie, albowiem do jego istoty należy przede wszystkim konieczność życia nim..$^{21} \mathrm{~A}$ to dlatego, że jedynie ci, którzy to czynią, dostępują z woli Bożej Jego sprawiedliwości $(2,13)$. Prawo nie może być traktowane jak talizman, obliczony na zachowanie tego, co się ma. W ręku Boga to narzędzie sądu. Dzięki niemu grzech nie staje się mniejszy, lecz przeciwnie, jeszcze bardziej grzeszny, gdyż popełniany jest w jego sferze $(7,13)$. To, co ono nakazuje, jest „dobre” i dlatego, gdy ludzie przestrzegają jego norm, czynią się sprawiedliwymi przed Bogiem. Prawdę tę apostoł dosadnie podkreśla, ponieważ stan sprawiedliwości przed Bogiem jest warunkiem niezbędnym do wydania przez Niego wyroku uniewinniającego, czyli do orzeczenia aktu usprawiedliwienia oskarżonego. Zatem jedynie przestrzeganie Prawa stanowi skuteczne zabezpieczenie korzystnego wyroku przed Bożym sądem (7,12; Ga 3,21n.). ${ }^{22}$

Skoro na tym polega istota Prawa i taką pełni ono funkcję w dziele usprawiedliwienia grzesznika, to dlaczego poganie, którzy nie mieli możliwości kierowania się normami Prawa, a czego oczekuje Bóg, mają „,zginąć” (2,11)? Dlaczego mają zostać ukarani, jeśli nie mogli być sądzeni zgodnie z procedurą prawną? Apostoł uważa również, że bez Prawa nie ma grzechu, że to dzięki niemu zdobywa się jego znajomość, że to ono „ożywia grzech” $(5,13 ; 7,7.9)$. Udzielając odpowiedzi na tak postawione pytania, stwierdza, że poganie wcale nie znajdują się poza sferą Prawa, choć rzeczywiście żyją poza sferą Prawa Mojżeszowego. Bo choć nie mają oni Prawa Mojżeszowego, to jednak ,z natury” ( fysis) swej czynią to, co nakazuje Prawo, a to oznacza - według Pawła - że sami dla siebie są Prawem z racji stworzenia ich przez Boga $(2,14)$. I to właśnie $z$ tej racji poganin może popełnić grzech, w konsekwencji czego grozi mu sąd i kara. Dlatego poganie nie mogą czuć się samowolni w tym, co czynią, lecz powinni

${ }^{21}$ Paweł jest w tym zgodny z ówczesną judaistyczną wykładnią Prawa Mojżeszowego; por. Rz 10,5; Ga 3,10nn.; Aboth III,10.

22 Por. C.K. B arret, The Epistle to the Romans, s. 47n.; R. H a ld a n e, Exposition of the Epistle to the Romans, s. 96; L.T. J o h n s o n, Reading Romans, s. 39. 
działać zgodnie ze swą „naturą” (fysis) stworzoną przez Boga, gdyż to w niej zapisał On swoje Prawo (swoją wolę) względem nich. Fakt ten sprawia, że sami są dla siebie Prawem. Postępując zaś w zgodności z samymi sobą, czyli Prawem Bożym zapisanym w ich naturze, będą „wypełniać dzieła Prawa” (ta tou nomou poiosin; 2,14). Paweł nie ma tu na myśli Mojżeszowego prawa rytualnego czy też moralnego, gdy stwierdza, że również i poganie są pod grzechem, ponieważ go nie znają. ${ }^{23}$ Mówiąc o „dziełach Prawa” (ta tou nomou) ma na myśli ,posłuszeństwo wierze" (hypakoēn pisteōs), zgodnie z tym co nakreślił w 1,5: „Przez Niego otrzymaliśmy łaskę i urząd apostolski, aby ku chwale Jego imienia pozyskiwać wszystkich Pogan dla posłuszeństwa wierze". W jego przekonaniu zatem tylko ,posłuszeństwo wierze” w Boga i konsekwentnie Jego Prawu, może stanowić jedyny godny fundament dla budowania relacji stworzenia ze Stwórcą. Rozpoznali to poganie, ale, niestety, postąpili źle w przeszłości gdy nawiązali relację ze stworzeniem a nie jego Stwórcą. Teraz jednak, w nowej rzeczywistości zbawczej, powinni to ,posłuszeństwo wierze” ponownie rozpoznać w pełnej prawdzie objawienia Bożego i zaakceptować je, ponieważ stworzenie powinno nawiązać relację ze prawdziwym Bogiem ze względu na swój los w wieczności. Odczuwali oni istnienie w swej naturze tej fundamentalnej konieczności nawiązania relacji ze Stwórcą, ponieważ jej pragnienie jest obecne w stworzeniu od początku jego zaistnienia (1,19nn.), odkąd Boże Prawo zostało „wypisane w jego sercu” $(2,15) .{ }^{24} \mathrm{Z}$ tej też racji, idąc za głosem serca, powinni oddać Bogu „cześć i dziękczynienie”, aby w ten właśnie sposób nawiązać z Nim właściwą relację, tę, jaką definiuje i wyznacza „posłuszeństwo wierze” w Niego i Jego wolę (Prawo). Jeśli człowiek wejdzie w tę relację i zaakceptuje Jego wolę, to będzie w stanie czynić wszystko, czego żąda od niego „natura ludzka” (fysis), czyli

23 Por. Rz 3,9; 3,19.23; 11,32; Ga 3,22.

24 Żydzi, w przeciwieństwie do pogan, otrzymali nadto szczególne objawienie Boże w swych dziejach oraz Jego Prawo za pośrednictwem Mojżesza. 
zapisane w niej (sercu), pochodzące od Stwórcy Prawo $(2,15) .{ }^{25}$ A że jest to możliwe, potwierdzają to ci poganie, którzy dokonują czynów wymaganych Prawem. Pokazują oni w ten sposób efekt funkcjonującego w ich sercach Prawa zapisanego tam przez Stwórcę w akcie stworzenia osoby ludzkiej. Obecne w jej „sercu” Prawo odciska swe „znamię" nie tylko w nim, lecz również i w jej umyśle, co uwidacznia się w rodzących się w nim myślach. O jego istnieniu i wpływie na serce i umysł zaświadcza „sumienie” (syneidessis), które Paweł nazywa ,świadkiem współświadczącym” (symmartyrousēs). ${ }^{26} \mathrm{~W}$ jego przekonaniu jest ono w stanie działać w charakterze ,świadka" opowiadającego się ,za” lub ,przeciw”. Nie może być przeciągane przez nikogo z zewnątrz na jedną lub drugą stronę, jak to bywa z ludzkimi świadkami. Może natomiast występować przeciwko jednej jak i drugiej stronie konfliktu myśli pojawiającego się w umyśle człowieka. Znajduje się między jedną a drugą stroną sporu, to znaczy między myślami broniącymi a myślami oskarżającymi $(2,15)$. Tak zróżnicowane działanie jest możliwe ponieważ daje ono świadectwo w bardzo ścisłej łączności z czymś, czego Paweł nie wymienia tu wprost, lecz z kontekstu należy wnosić, że chodzi mu z całą pewnością o Prawo. I to właśnie z nim ,współświadczy” (symmartyrei) w konkretnej sprawie, rozstrzygając powstały spór, wewnętrzną sprzeczność myślii. ${ }^{27} \mathrm{~W}$ przypadku poganina nie może to być Prawo Mojżeszowe, ponieważ go nie zna. Może nim być jedynie Prawo naturalne. Jest ono zatem świadkiem toczącej się wewnątrz umysłu

25 Paweł odwołuje się tu do myśli stoickiej, neoplatońskiej i Filona, rozpowszechnionej w świecie hellenistycznym, a za pośrednictwem Filona również w judaizmie diaspory. Współczesny mu judaizm oraz pisma rabinackie nie mówią nic o Prawie wypisanym w sercach pogan. Jest ono wypisane w sercach Izraelitów, zgodnie z obietnicą Boga przekazaną za pośrednictwem proroka Jeremiasza (31,33); por. J-N. A 1 e t t i, List do Rzymian, s. 1420; C.K. B a r r e t, The Epistle to the Romans, s. 49; R. H a ld a n e, Exposition of the Epistle to the Romans, s. 97.

26 Podobnie jak w 9,1 i 2 Kor 1,12.

27 Symmartyreō - „,dawać świadectwo wraz z [kimś]”, „świadczyć wraz z [kimś]”, ,poświadczać wraz z [kimś]”". 
debaty myśli inspirowanych Prawem Bożym, ${ }^{28}$ dlatego myśli oskarżających bądź usprawiedliwiających człowieka przed dawcą tegoż Prawa. W przekonaniu apostoła jest więc świadkiem Bożego Prawa wypisanego w sercu i jednocześnie działającego w umyśle ludzkim, w jego myślach tam powstających, tj. w jego świadomości budowanej i formowanej przez nie. Świadomości przekonanej, z jednej strony, o naturalnym Prawie Bożym obecnym w sercu i umyśle ludzkim, z drugiej zaś, odczytującej w sobie konieczność dokonywania osądu wszystkich zachowań człowieka w jego świetle i pod jego rygorem. ${ }^{29}$

Paweł jest przekonany, że prawdziwość przedstawionej tu wykładni zostanie potwierdzona w „dniu sądu” $(2,16)$. Bóg, jako sędzia sprawiedliwy, osądzi w nim wszystkie czyny ludzkie, jawne i ukryte. ${ }^{30}$ Zaskakująca dla Żydów i Greków jest tu zapewne zapowiedź, że Bóg nie dokona go ani na podstawie Prawa Mojżeszowego ani Prawa naturalnego, lecz Ewangelii głoszonej przez apostoła: ,według mojej Ewangelii" (kata ton euaggelion mou). Dlaczego właśnie według niej? Ponieważ, jak to wyraził w propositio do całego listu, ,jest ona bowiem mocą Bożą ku zbawieniu dla każdego wierzącego, najpierw dla Żyda potem dla Greka” $(1,16)$. Apostoł, wieńcząc w taki właśnie sposób argumentację całej tej jednostki retorycznej, wzywa więc adresatów do życia Ewangelią Jezusa. Apel ten wzmacnia jeszcze bardziej, gdy zapowiada, że Bóg dokona sądu ,przez Chrystusa Jezusa” (dia Christou Iēsou). Zatem Żydom nie wystarczy już Prawo

28 Paweł nie mówi w tym miejscu wprost o Prawie naturalnym, ale wynika to bezpośrednio z kontekstu.

29 Pawłowy opis sposobu działania sumienia jest próbą oddania niejasnego greckiego zwrotu metaksy allēlōn - ,między jednymi a drugimi”; por. C.K. B a r r e t, The Epistle to the Romans, s. 50n.; R. H a ld a n e, Exposition of the Epistle to the Romans, s. 98n.; L.T. J o h n s o n, Reading Romans, s. 40; J.M. B o i c e, Romans I, s. 232-240; R. J e w e t t, Romans, s. 207-216; R. K r a w c z y k, Prawo wpisane w secach ludzkich. Studium egzegetyczno-teologiczne (Rz 2,15), Wiadomości Diecezji Siedleckiej 2/2009, s. 102-111.

30 Na co wskazuje przez bezpośrednią wzmiankę o „,czynach ukrytych”. Dlatego Bóg bada serce, a nie postępowanie człowieka, żeby się przekonać o jego winie lub sprawiedliwości (Pwt 4,29; 6,5; 1Sm 16,7). 
Mojżeszowe, a poganom Prawo naturalne. Jedni i drudzy muszą wyznać wiarę i zacząć kształtować swoje serca i umysły (sumienia) Ewangelią, ponieważ tylko w ten sposób zaopatrzą się w „Moc Bożą” wiodącą niezawodnie do zbawienia, którego nie byli w stanie zdobyć na drodze Prawa. ${ }^{31}$

\section{Obrzezane serce kryterium sprawiedliwości Bożej}

Do tej pory Paweł debatował o przywileju Prawa w terminach ogólnych. Od 2,25-29 przechodzi do konkretów. Na twierdzenie, że Żydzi mają obrzezanie, którego nie mają poganie, odpowiada, że obrzezanie oczywiście ma wartość, ale tylko pod warunkiem że jest przestrzegane Prawo. Neguje w ten sposób przekonanie Żydów, że nie wolno przeciwstawiać obrzezania Prawu, albowiem obrzezanie jest jego częścią i nie można go praktykować nie będąc obrzezanym. Dla apostoła bowiem dokonywanie dzieł wymaganych przez Prawo nie polega na drobiazgowym wypełnianiu wszystkich zapisanych w nim przepisów, lecz miało ono służyć budowaniu właściwej relacji z Bogiem. To jest prawdziwy sens i cel nadany mu przez Boga, albowiem relacja z Nim nie ma polegać na posłuszeństwie legalistycznym, lecz na „posłuszeństwie wierze” (3,31; 9,31n.; 10,16nn.; por. 1,5). Dlatego dalej autorytatywnie stwierdza, co brzmi bez wątpienia bardzo kontrowersyjnie dla Żydów, że jeżeli obrzezany przekracza Prawo, to

przez ten akt sam siebie czyni nieobrzezanym. Żyd, który chlubi się widocznym obrzezaniem ciała, traktując je jako znak pierwszeństwa i wyższości, nadto niezawodnie gwarantujący mu zbawienie, takim sposobem myślenia sam niszczy komunię z Bogiem i tym samym automatycznie pozbawia sensu swoje obrzezanie. A to oznacza, że nie jest już dłużej obrzezanym w prawdziwym tego słowa znaczeniu $(2,25.29)$, ponieważ przestaje być ono znakiem relacji zdefiniowanej przez Przymierze. Jeżeli Żyd jawnie przekracza Prawo, będąc obrzezanym, to tym samym przekracza je również wewnętrznie. Dzieje się tak, ponieważ ma on świadomość, że to samo Prawo zobowiązuje

31 Por. J.M. B o i c e, Romans I, s. 240-247; R. J e w e t t, Romans, s. 217n. 
go do jego przestrzegania. To zaś oznacza, że rozumie, iż całkowicie należy do Boga przez obrzezanie i Prawo. Konsekwentnie zatem dobrze wie, że nie ma żadnych podstaw do tego by wykorzystywać jedno i drugie do chełpienia się przed tymi, którzy tego nie mają. ${ }^{32}$

Unieważnienie obrzezania przez samego Żyda z powodu nieprzestrzegania przez niego Prawa, pociąga za sobą daleko idące konsekwencje również dla sytuacji pogan. Apostoł wyjaśnia, że jeśli nieobrzezany Grek zachowuje przepisy Prawa, to nawet brak u niego cielesnego obrzezania nie przeszkodzi Bogu uznać go (,policzyć”) 33 za obrzezanego $(2,26) .{ }^{34}$ Dla Boga bowiem widoczne obrzezanie jest nieistotne, najważniejsze jest bowiem to, co ma ów zewnętrzny znak wyrażać, a mianowicie duchowo obrzezane serce - serce oddane i całkowicie Mu posłuszne. Jeśli takie serce ma Grek, to Bóg „policzy” go za pełnoprawnego członka swojego ludu, tak jak rodzonego Żyda. Ma On do tego absolutnie niczym nieograniczone prawo. Skoro bowiem sam polecił obrzezanie, to jest też całkowicie wolny w dysponowaniu nim według swojej zbawczej woli. Co więcej - dodaje Paweł - może się tak stać, że nieobrzezany od urodzenia Grek, który wypełniał Prawo, będzie sędzią Żyda, który od urodzenia jest obrzezany i ma księgę Prawa, lecz nie respektował w swym życiu ani jednego, ani drugiego (2,27; por. Mt 12, 41n.). Jest to możliwe, ponieważ - jak to wcześniej wyłożył - Bóg dokona sądu nie na podstawie Prawa Mojżeszowego, lecz opierając się na Ewangelii głoszonej przez niego $(2,16)$. Stanie się tak jednak wtedy, gdy Grek okaże posłuszeństwo wierze i wyzna wiarę w Jezusa Chrystusa, przez którego to Bóg będzie sądził wszystkich $(2,26) .{ }^{35}$

Prowadzona w drugim rozdziale listu krytyka służy Pawłowi do ukazania płynności wszelkich różnic i granic między Żydami

\footnotetext{
32 Por. C.K. B a r r e t, The Epistle to the Romans, s. 54.

33 Zastosowany tu czasownik logisthēsetai to passivum divinum. Wyraża czynność, której podmiotem jest Bóg; por. tamże, s. 55.

34 Paweł powraca tu do argumentów przedstawionych w 2,14n., aby je szerzej rozwinąć.

35 Por. C.K. B a r r e t, The Epistle to the Romans, s. 55n.
} 
i Grekami - obrzezanymi i nieobrzezanymi. ${ }^{36}$ Odwołuje się w tym do nauczania proroków, którzy kryterium sprawiedliwości Bożej widzieli w obrzezanym sercu, a nie literze Prawa, jego legalistycznym przestrzeganiu. Apostoł jednak nie pozbawia wartości takich pojęć jak „Żyd” i „obrzezanie”, lecz nadaje im nowe znaczenia. Dokonuje ich redefinicji w podwójnym sensie: negatywnym i pozytywnym (2,28n.). Według nowej definicji „Żydem nie jest ten, który jest nim na widoczności, ani obrzezanie nie jest to, które jest widoczne na ciele” $(2,28)$. Gdy Paweł mów o „Żydzie na widoczności” (en tō fanerō Ioudaios) to nie ma na myśli Żyda obrzezanego cieleśnie. Chodzi mu bardziej o charakterystykę jego postaw i zachowań. „Widoczny Żyd” to ten, który, jako cieleśnie obrzezany, na zewnątrz wykonuje przepisy Prawa w tym celu, aby zademonstrować swą przynależność religijną do ludu Bożego, traktując to oczywiście jako przywilej,j którym może jawnie szczycić się przed światem. „Ukryty Żyd” (kryptō Ioudaios) według Pawła nie wyróżnia się zewnętrznym znakiem, lecz wewnętrznym posłuszeństwem w wierze $(1,5)$, bowiem tym czego rzeczywiście wymaga Prawo jest żywa wiara w Boga, oznaczająca osobową komunię z Nim. Tylko Bóg może prawidłowo rozstrzygnąć, kto jest prawdziwie obrzezanym Żydem, gdyż tylko On zna serce ludzkie. Paweł, gdy mówi o „ukrytym Żydzie”, nie ma na myśli dobrego, skromnego Żyda, który nie chlubi się swym przywilejem pierwszeństwa i statusem religijnym. Apostoł wie, że decyzja o ludzkiej skromności, dobroci, cnocie czy też grzechu należy do Boga. Dlatego też „,ukryty Żyd”, czyli prawdziwy Żyd, to ten, kto zadeklarował się być takim przed Bogiem. To ten, kto staje w pełnej wewnętrznej prawdzie wobec Niego, z sercem obrzezanym, tj. w pełni otwartym, szczerym, prostodusznym, pokornym, posłusznym i oddanym (por. Pwt 10,16; 30,6; Jr 4,4). ${ }^{37}$

36 Por. J.-N. A l e t t i, List do Rzymian, s. 1422.

37 Por. C.K. B a r r e t, The Epistle to the Romans, s. 57; L.T. J o h n s o n, Reading Romans, s. 42; J.M. B o i c e, Romans I, s. 256-264; R. J e w e t t, Romans, s. 231-236. 


\section{Powszechność grzechu wśród Żydów i Greków}

W 3,1-20 Paweł wprowadza radykalną zmianę ilościową w ocenie sytuacji ludzkości wobec Bożego sądu i odpłaty. Nie chodzi mu już tylko o tych grzesznych z trzech wcześniej wymienionych grup, lecz o k a ż de g o człowieka bez wyjątku, ka żde go Greka i ka ż d e g o Żyda, nawet tego pobożnego, o którym wspomina w kontekście charakterystyki dopuszczających się niesprawiedliwości. ${ }^{38}$ Koronnym dowodem, absolutnie niepodważalnym, wskazującym na taki właśnie stan całej ludzkości jest Pismo - słowo Boże, świadectwo samego Boga znającego każde ludzkie serce (por. Rz 3,10-18; Ps 14[13],1n.; 5,10; 140[139],4; 10[9],7; Iz 59,7n.; Ps 36[35],2). Paweł ich nie zna. Dlatego nie może sam oskarżać całej ludzkości o grzeszność. Musi odwołać się do dowodów z Pisma Świętego. Do zawartego w nim sądu samego Boga, żeby przedstawić wiarygodne dowody. ${ }^{39}$

Stwierdzeniem w 3,4, że „każdy człowiek jest kłamliwy”, Paweł odwołuje się do Ps 115[114],11 i przypomina identyczną konstatację psalmisty. Potwierdza tekstem świętym postawianą przez siebie tezę o powszechności grzechu. W 3,9-18 przywołuje kolejne świadectwa słowa Bożego. ${ }^{40} \mathrm{~W} 3,10-12$ odwołuje się do Ps 14[13],1-3, by wskazać na powszechność zła. W 3,13a mówi o całkowitej deprawacji, do której przyczyniło się ludzkie ,gardło” i ,język” (Ps 5,10). W 3,13b wymienia ,wargi” jako źródło zła (Ps 140[139],4), w 3,14 „usta” (Ps 10[9],7),

38 W 3,4.19 - „każdy”; 3,9 - „, ani jednego”; 3,12 - „wszyscy”. Nie oznacza to jednak negacji wybrania i wynikającego z niego pierwszeństwa i wyższości Żydów. Wyjaśnia to jeszcze raz w 3,1-8, wskazując na nowe aspekty relacji naród - Bóg. Dzięki obrzezaniu Żydzi otrzymali słowo Boże, lecz, niestety, lud okazał się niewierny, odstępując od warunków zawartego Przymierza. Pokazali, że są kłamcami; przyrzekli przecież je zachowywać. Mimo ich niewierności Bóg nie przestaje być wierny.

39 Paweł nie może odwołać się tu do osobistego doświadczenia, gdyż jego argumenty nie zostałyby przyjęte przez pobożnych Żydów; por. J.-N. A 1 e t 1 i, List do Rzymian, s. 1417.

40 Tezą o powszechności grzechu postawioną w 3,4 apostoł przygotowuje grunt pod dalsze dowody biblijne przedstawione w 3,10-18. 
a w 3,15-17 „nogi” i ,drogę” (Iz 59,7-8). Werset 3,18 (Ps 36[35],2) jako paralelny do 3,10-12 buduje z nim klamrę spinającą katalog dowodów biblijnych potwierdzających zepsucie całego człowiek, od stóp aż po głowę. Pokazując grzesznika w całej swej integralności cielesnej, apostoł wzmacnia swój przekaz o powszechności grzechu: grzeszna jest absolutnie cała ludzkość, każdy i cały człowiek. ${ }^{41}$

$* * *$

Zanim Paweł przejdzie do tematyki chrystologiczno-soteriologicznej (od 3,21), przypomina swoim adresatom biblijne i żydowskie idee o karzącej sprawiedliwości Bożej $(1,18$ - 3,20). Były one bardzo żywe w judaizmie jego epoki, a co za tym idzie również wśród adresatów jego listu. Dla ludzi doświadczających różnego rodzaju niesprawiedliwości i oczekujących z jej powodu Bożej interwencji były oczekiwane z nieskrywaną niecierpliwością.

W 1,19-32 apostoł ukazuje sytuację zbawczą tych ludzi, którzy odrzucili Boga i Jego sprawiedliwość, oddając się złym uczynkom. Od 2,1 do 3,20 zmienia dotychczasową spokojną narrację w ożywiony dyskurs z kolejnymi adwersarzami, starając się podważyć podtrzymywane przez nich tradycyjne idee o Bożej sprawiedliwości, dotyczącej Żydów i Greków. Nie daje jednak żadnych okazji ku temu, by adresaci mogli identyfikować stawiane przez Pawła zarzuty jedynie z Żydami bądź też wyłącznie z Grekami. Stosuje terminologię ogólną $\mathrm{w}$ formie bezosobowej, koncentrując się nie na całych narodach, lecz na działaniach ludzkich. Nie mówi o wszystkich, lecz o tych, którzy czynią zło i akceptują takie działanie u siebie i u innych (1,19-32), oraz o tych, którzy krytykują i osądzają ludzi z pierwszej grupy, lecz sami dopuszczają się podobnej niesprawiedliwości (2,1-8). Apostoł nie ukrywa, że jednych i drugich dosięgnie sąd i surowa kara Boża (2,9-11), nagrodę zaś otrzymają ci, którzy postępują dobrze, reprezentujący zarówno Żydów jak i Greków (2,14-15). Do trzeciej grupy

${ }^{41}$ Por. J.-N. A 1 e t t i, List do Rzymian, s. 1422; L.T. J o h n s o n, Reading Romans, s. 43n.; 264-335; R. J e w e t t, Romans, s. 238-266. 
zalicza wyłącznie tych Żydów, którzy głoszą dobro, lecz sami dopuszczają się zła (2,17-24). Drugą i trzecią grupę grzeszników łączy wspólna im wewnętrzna sprzeczność. Polega ona na tym, że każdy $\mathrm{z}$ nich potępia innych z powodu złego postępowania, tymczasem sam postępuje identycznie jak ci, których tak surowo osądza. Paweł przypomina, że istnieje ścisły związek między ludzkim działaniem, a Bożą reakcją na nie. Dlatego każdy człowiek musi czuć się odpowiedzialny przed Bogiem za swoje czyny. Jednocześnie dodaje, że Bóg nie potępia definitywnie grzesznika. Nie unicestwia go z powodu jego grzechów, lecz karze go zawsze z umiarem, proporcjonalnie do popełnionego zła, wzywając go w ten sposób do nawrócenia.

Dokonując szczegółowej analizy czynów ludzkich, wykazuje, że sam fakt posiadania przez Żydów Prawa Mojżeszowego nie daje im gwarancji i nie sprawia automatycznie, że wszystkie dokonywane przez nich czyny są zgodne z objawioną wolą Bożą. Dla Pawła, jakakolwiek by nie była różnica między Żydami i poganami, to i tak nie jest ona na tyle istotna, by była w stanie wpłynąć na podstawę i werdykt sądu Bożego. Bowiem Bóg sądzi czyn ludzki wyłącznie według kryterium „prawdy” $(2,2)$. Dostrzega wewnętrzną świętość lub zło każdego człowieka, ponieważ doskonale zna jego serce. Żydzi, dzięki Prawu, mieli być dla pogan nauczycielami, przewodnikami i światłem wszelkiej wiedzy i prawdy o jedynym prawdziwym Bogu. Niestety, nie wszyscy z nich tej misji sprostali, dopuszczając się w ten sposób najcięższego ze wszystkich grzechów. Z tego powodu stali się równi poganom, którzy zamiast dzięki nim poznać prawdziwego Boga i żyć zgodnie z Jego Prawem, nadal „bluźnią Jego imieniu” $(2,24)$. Popełniony grzech w sposób oczywisty spowodował utratę przez nich tożsamości żydowskiej. To, co miało okazać się dla nich przywilejem i korzyścią, wcale tym nie było. Podobnie jak i dla pogan brak jednego i drugiego przywileju nie okazał się korzystny, albowiem nie uchroniło ich to przed grzechami i Bożym sądem.

Ostatecznie zarówno Żydzi jak i poganie znaleźli się w tym samym grzesznym położeniu i dlatego na równi będą sądzeni. Poganie nie znajdują się bowiem poza sferą Prawa, choć rzeczywiście nie znają objawionego Prawa Mojżeszowego. Jednak z natury swej czynią 
to, co nakazuje Prawo, a to oznacza, że sami dla siebie są Prawem $z$ racji stworzenia ich przez Boga. I to właśnie dlatego poganie moga popełnić grzech, w konsekwencji czego grozi im sąd i kara. Dlatego nie mogą czuć się samowolni w tym, co czynią, lecz powinni działać zgodnie ze swą naturą dana mu przez Boga, w której zapisał On swoją wolę. Fakt ten sprawia, że sami są dla siebie Prawem. Postępując zatem w zgodności ze sobą, spełniają uczynki Prawa Bożego, w przeciwnej sytuacji dokonują dzieł sprzecznych z nim, zatem dopuszczają się zła, o czym daje świadectwo ich sumienie.

Według Pawła, obrzezanie Żydów ma wartość, ale tylko pod warunkiem że przestrzegają Prawa. To zaś polega nie na drobiazgowym wypełnianiu jego przepisów, lecz na budowaniu właściwej relacji z Bogiem, która w Jego założeniu miała polegać nie na posłuszeństwie legalistycznym, lecz na posłuszeństwie wierze. Dlatego jeżeli obrzezany Żyd przekracza Prawo, to przez ten akt sam czyni nieobrzezanym Grekiem, niszcząc w ten sposób komunię z Bogiem, i tym samym automatycznie pozbawia właściwego sensu swoje obrzezanie. A to oznacza, że nie jest już dłużej obrzezanym w Bożym rozumieniu tego słowa. I, konsekwentnie, jeśli nieobrzezany Grek zachowuje przepisy Prawa wypisanego w jego sercu, to nawet brak u niego cielesnego obrzezania nie przeszkadza Bogu uznać go za obrzezanego duchowo. Dla Boga bowiem obrzezanie cielesne nie jest istotne, najważniejsze jest bowiem obrzezane serce - serce oddane i całkowicie Mu posłuszne. Jeśli takie serce ma Grek, to Bóg uznaje go za pełnoprawnego członka swojego ludu, tak jak rodzonego Żyda. Co więcej, może się okazać, że nieobrzezany od urodzenia Grek, który wypełniał Prawo, będzie sędzią Żyda od urodzenia obrzezanego i mającego księgę Prawa, lecz nie respektującego w swym życiu ani jednego, ani drugiego.

Wprowadza też nową definicję Żyda w sensie negatywnym i pozytywnym. Dla niego ,widoczny Żyd” to ten, który, jako obrzezany na ciele, wykonuje przepisy Prawa w tym celu, aby demonstrować na zewnątrz swą przynależność religijną do ludu Bożego, traktując ją jako przywilej, którym może szczycić się przed światem pogańskim. Natomiast „ukryty Żyd” to ten, kto zadeklarował się takim być przed 
Bogiem. To ten, kto staje w pełnej wewnętrznej prawdzie wobec Niego, z sercem obrzezanym, tj. całkowicie otwartym, szczerym, prostodusznym, pokornym, posłusznym i oddanym. Paweł wykazuje jednak, że prawdziwym Żydem może być również poganin obrzezany w swoim sercu, obok Żyda obrzezanego fizycznie na ciele i duchowo w sercu.

W prowadzonej argumentacji od samego początku zamierza on doprowadzić Żydów i Greków do jedynego kryterium rozstrzygającym o tym, kto jest sprawiedliwy przed Bogiem, a kto takim nie jest. Jest nim obrzezane serce, które nie jest jednak zastrzeżone wyłącznie dla Żydów. Albowiem Bóg, gdy sądzi, nie spełnia swej sprawiedliwości na podstawie kategorii zewnętrznych, lecz kieruje się kryterium uczynków i obrzezanego serca ludzkiego oraz osobistą bezstronnością.

Paweł przypomina też, że przywracanie przez Boga sprawiedliwości nie polega jedynie na karaniu ludzi według stopnia popełnionego przez nich zła, lecz przede wszystkim na naprawianiu dokonanego przez nich zła. Na zadośćuczynieniu pokrzywdzonym przez nich, na udzielaniu im swoich atrybutów, takich jak: bezstronność, chwała, cześć i pokój. Paweł nie zapomina o ludziach dobrych, gdyż pomagają mu w ukazaniu Boga traktującego tak samo zarówno dobrych Żydów jak i dobrych pogan. To zaś służy mu do wzmocnienia zakwestionowania odrębnych tożsamości religijnych Żydów i Greków, a tym samym i wynikających z nich zróżnicowanych nagród i kar dla jednych i drugich ze względu na ich różny status religijny.

W 3,1-20 apostoł dopełnia dotychczasowe argumenty postawieniem radykalnej tezy o powszechności zła, którą to uzasadnia dowodami biblijnymi. Traktuje ją jako ostatni już argument służący mu zupełnemu zatarciu dotychczasowych różnic i granic między Żydami i poganami. Na podstawie przytoczonych tekstów biblijnych dowodzi, że wszyscy oni, bez żadnego wyjątku i przywileju, są grzesznikami, a więc znajdują się w tej samej sytuacji względem sprawiedliwości Bożej, zatem jedni i drudzy będą tak samo sądzeni i ukarani.

Wszystkie przedstawione w sekcji 1,18-3,20 argumenty i dowody nie służą jednak Pawłowi do wyrwania grzesznej ludzkości z letargu 
zła, uświadomienia jej wielkości grzechu i zmuszenia do upokorzenia się przed Bogiem w głębokim żalu i szczerej skrusze. Chce natomiast przede wszystkim wyjaśnić, że skoro cała ludzkość znalazła się w takiej samej sytuacji grzechu, sądu i kary, to również cała ludzkość, w ten sam sposób, bez żadnego wyjątku i przywileju dla Żydów bądź Greków, zostanie usprawiedliwiona, uwolniona od jej grzechów oraz surowego sądu i kary potępienia. Wszyscy zostaną „usprawiedliwieni” (dikaioumenoi/dikaiosynē) przez tę samą wiarę w Jezusa. Jedni i drudzy dostąpią go tak samo ,za darmo, z Jego łaski, przez odkupienie, które jest w Chrystusie Jezusie” (3,24). „Jego to bowiem ustanowił Bóg narzędziem przebłagania przez wiarę mocą Jego krwi” (3,25a). Dla Pawła jest oczywiste, że to wyłącznie w Jezusie, a nie jak dotychczas przez uczynki Prawa Mojżeszowego bądź naturalnego, Boża łaskawa sprawiedliwość stała się dostępna dla każdego człowieka. Dla każdego Żyda i każdego Greka (3,21-23), bowiem - jak argumentuje - każdy ,człowiek osiąga usprawiedliwienie przez wiarę, niezależnie od pełnienia nakazów Prawa” $(3,28)$. Dokonuje się to na podobieństwo Abrahama, gdy ten wykazał się wiarą, a Bóg poczytał mu to za sprawiedliwość (4,1-25), bowiem jak dowodzi apostoł - ,,jeden jest tylko Bóg, który usprawiedliwia obrzezanego dzięki wierze, a nieobrzezanego przez wiarę" $(3,30)$. $Z$ tej nowej rzeczywistości zbawczej rodzi się nowe wspólne życie i nadzieja dla Żydów i Greków (5-8) oraz nowa przyszłość dla Izraela i pogan (9-11).

ks. Zdzisław ŻYWICA

Słowa kluczowe: Żyd, Grek, Prawo, obrzezanie, sąd, kara, sprawiedliwość, wiara, Jezus, usprawiedliwienie

Key words: Jew, Greek, Law, circumcision, judgment, punishment, justice, faith, Jesus, justification 


\section{Circumcised Greek and True Jew in the Light of Romans 1,18-3,20 Summary}

The essential Christological and soteriological message of the Letter of St. Paul to the Romans precedes with the reflection on the biblical idea of the retributive justice of God. He does not do it to humiliate Jews and Gentiles because of the sin in which they lapsed, or to make them aware of their equally hopeless situation before God, or even to force them to humiliate themselves in grief and repentance before God the Judge. He wants to explain to the addressees of the letter why God intended to justify them all together in the same way, without taking into account the primacy of the privilege of the Jews, nor the permanent godlessness of the Gentiles. Both were simply sinners, which caused them to find themselves in the same situation with respect to the righteousness of God's judgment and punishment. Therefore, all without exception, as sinners both Jewish and pagan, will attain justification in the same way, namely by faith in Jesus Christ. 